\title{
Evaluation of pulsed-field gel electrophoresis for typing of Shigella dysenteriae type 1
}

\author{
K. A. TALUKDER, D. K. DUTTA and M. J. ALBERT \\ Laboratory Sciences Division, International Centre for Diarrhoeal Disease Research, Bangladesh (ICDDR,B), \\ GPO Box 128, Dhaka 1000, Bangladesh
}

\begin{abstract}
Pulsed-field gel electrophoresis (PFGE) has been used successfully to discriminate between strains of many different bacterial species. In this study, digestion of bacterial DNA with the restriction endonuclease Not I and PFGE were evaluated for the typing of isolates of Shigella dysenteriae type 1 , an important cause of epidemic dysentery. There were 27 isolates from four outbreaks of dysentery, and 44 isolates from endemic dysentery cases and a laboratory culture collection. The epidemic isolates yielded two types each with two subtypes, whereas the endemic isolates and culture collection yielded eight types with numerous subtypes. These findings suggest that $S$. dysenteriae 1 can be typed by PFGE.
\end{abstract}

\section{Introduction}

The genus Shigella is divided into four species: $S$. dysenteriae, $S$. flexneri, $S$. boydii and $S$. sonnei. The first three species are further subdivided into several serotypes based on agglutination with monospecific antisera. In $S$. dysenteriae, there are 10 or more serotypes [1]. $S$. dysenteriae type 1 has been responsible for epidemics of dysentery in Asia, Latin America and Africa in recent times [2]. It is also routinely isolated from endemic dysentery cases [3].

Strain discrimination is important for epidemiological studies. Analyses of plasmid content and antimicrobial susceptibility patterns have been used in the past for strain discrimination of certain Shigella spp. [4, 5]. However, these methods have limitations, as plasmids are unstable and, in many instances, antimicrobial resistance is encoded by plasmids [6]. These methods have now been superseded by ribotyping, which relies on polymorphism in the regions surrounding the rRNA genes [7], and pulsed-field gel electrophoresis (PFGE) of whole chromosomal DNA [8]. In the latter method, chromosomal DNA is digested with a restriction endonuclease that generates large fragments. The restriction fragments are resolved into a pattern of discrete bands in an agarose gel in which the orientation of the electric field across the gel is changed

Received 10 Sept. 1998; revised version accepted 20 Jan. 1999.

Corresponding author: Dr M. J. Albert (e-mail: albert@ icddrb.org). periodically ('pulsed') rather than kept constant as in conventional agarose gel electrophoresis. The DNA restriction patterns of the isolates are then compared with one another to determine their relatedness. PFGE has been employed successfully for strain discrimination of a variety of bacteria, including $S$. sonnei $[9,10]$, which is the predominant species causing dysentery in developed countries. However, to our knowledge, there has been no study where this technique was used for strain discrimination of $S$. dysenteriae type 1 , which is an important cause of dysentery in developing countries. Therefore, the present study evaluated the utility of PFGE in typing $S$. dysenteriae type 1 isolates.

\section{Materials and methods}

The $S$. dysenteriae type 1 strains that were studied are shown in Table 1 and include isolates from both epidemic and endemic dysentery cases. The epidemic isolates from Calcutta were provided by S. C. Pal, National Institute of Cholera and Enteric Diseases, Calcutta, India [11]. Teknaf and Rangpur isolates were from epidemics that occurred in south-eastern and northern parts of Bangladesh, respectively, in 1985 $[6,12]$. The isolates from Bombay were from a local outbreak in 1978 and were provided by L. P. Deodhar, LTM Medical College, Bombay, India. The isolates from endemic dysentery cases were from Matlab and Dhaka in Bangladesh, Bangalore in southern India, and the culture collection at the Centers for Disease Control (CDC), Atlanta, GA, USA. The Indian isolates were provided by P. Bhat, St John's Medical College, 
Bangalore, India, and the $\mathrm{CDC}$ isolates were provided by G. W. Grady. Both the epidemic and endemic isolates from Bangladesh were cultured at the microbiology laboratories of the International Centre for Diarrhoeal Disease Research, Bangladesh (ICDDR,B), located either in Dhaka or Matlab and which are separated by $45 \mathrm{~km}$. There were no data on how many subcultures the bacterial isolates had undergone before they were received at this laboratory. On receipt, the cultures were stored at $-70^{\circ} \mathrm{C}$ in Trypticase Soy Broth (Difco, Detroit, MI, USA) with glycerol $15 \%$. The identity of the isolates was confirmed by biochemical reactions and agglutination with specific antiserum [13].

DNA for PFGE was prepared as described by Smith $e t$ al. [14]. PFGE was performed with the contourclamped homogeneous electric field (CHEF-DRII) apparatus from BioRad Laboratories (Richmond, CA, USA) as described previously [15], but with different pulse times as described below. Genomic DNA in Clean-Cut Agarose (BioRad) 1\% was digested with restriction endonucleases (Gibco BRL, Gaithersburg, MD, USA) and incubated overnight at $37^{\circ} \mathrm{C}$. DNA was electrophoresed on Pulsed Field Certified Agarose (BioRad) $1 \%$ at $200 \mathrm{~V}$ for $40 \mathrm{~h}$ with the following pulse times: 5-50 s $(12 \mathrm{~h}), 20-80 \mathrm{~s}(12 \mathrm{~h})$ and $60-$ $120 \mathrm{~s}(16 \mathrm{~h})$. The DNA size standards used were the bacteriophage $\lambda$ ladder ranging from 48.5 to $1000 \mathrm{~kb}$ (BioRad) and Saccharomyces cerevisiae chromosomal DNA ranging from 225 to $2200 \mathrm{~kb}$ (BioRad). Band sizes were determined by measuring the migration distances of the bands and extrapolation to a standard curve of migration distance against the logarithmic molecular size of the DNA size standards. Band patterns were established by the criteria described by Tenover et al. [8]. Isolates were considered genetically indistinguishable if they possessed PFGE patterns with the same number and same size of bands.

Closely related strains differed by changes consistent with a single genetic event (two-to-three band differences) and possibly related strains differed by changes consistent with two independent events (four-to-six band differences). Unrelated strains differed by three or more independent genetic events (seven or more band differences).

\section{Results}

Initial studies were performed with 10 strains of $S$. dysenteriae type 1 from the collection and several restriction endonucleases, including NotI, $X b a \mathrm{I}, \operatorname{SmaI}$ and $\mathrm{Cla}$ I (Gibco BRL). The best discrimination, with easily interpretable patterns, was obtained with $N o t \mathrm{I}$; $X b a \mathrm{I}$ produced numerous fragments, while $S m a \mathrm{I}$ and $\mathrm{Cla}$ I did not yield restriction fragments of uniform size distribution (data not shown). Therefore, further studies were performed with NotI. To determine the stability of the pattern, the 10 isolates were subcultured five times and, after each subculture, the pulsed-field gel patterns were determined after digestion with Not I. The patterns remained unchanged after each subculture (data not shown).

The PFGE patterns obtained with the epidemic and endemic isolates are shown in Table 1. The representative patterns are shown in Fig. 1a-c. As examples of discrimination between subtypes, in Fig. 1a, subtype A1 (lane 3) and subtype A2 (lane 4) differed by the mobilities of two bands indicated by vertical arrows; subtype A2 and subtype A3 (lane 5) differed by the mobilities of four bands indicated by arrow heads.

The major types differed by seven-to-eight bands and the subtypes differed by two-to-five bands. The epidemic isolates were homogeneous, with a maximum of two subtypes in each group (A1 and A2, and B1 and B2). Isolates from Teknaf and Rangpur in Bangladesh were identical to the isolates from Calcutta, India. The isolates that caused the outbreak in Bombay in the central-western part of India were quite distinct. The endemic isolates from India and Bangladesh, and the isolates from the CDC collection, were heterogeneous. Even so, among the endemic isolates, there

Table 1. PFGE patterns of $S$. dysenteriae 1 isolates

\begin{tabular}{|c|c|c|}
\hline Source (year) & $\begin{array}{c}\text { Number of } \\
\text { isolates }\end{array}$ & $\begin{array}{c}\text { PFGE } \\
\text { pattern* }\end{array}$ \\
\hline \multicolumn{3}{|l|}{ Epidemic isolates } \\
\hline Calcutta, India (1984) & $\begin{array}{l}7 \\
6\end{array}$ & $\begin{array}{l}\mathrm{A} 1 \\
\mathrm{~A} 2\end{array}$ \\
\hline Teknaf, Bangladesh (1985) & 3 & A1 \\
\hline Rangpur, Bangladesh (1985) & $\begin{array}{l}1 \\
4\end{array}$ & $\begin{array}{l}\mathrm{A} 1 \\
\mathrm{~A} 2\end{array}$ \\
\hline Bombay, India (1978) & $\begin{array}{l}4 \\
2\end{array}$ & $\begin{array}{l}\mathrm{B} 1 \\
\mathrm{~B} 2\end{array}$ \\
\hline \multicolumn{3}{|l|}{ Endemic isolates } \\
\hline Matlab, Bangladesh (1987) & $\begin{array}{l}2 \\
2 \\
1 \\
1 \\
1\end{array}$ & $\begin{array}{l}\mathrm{A} 1 \\
\mathrm{~A} 2 \\
\mathrm{~A} 3 \\
\mathrm{C} \\
\mathrm{D}\end{array}$ \\
\hline Dhaka, Bangladesh (1997) & $\begin{array}{r}11 \\
1 \\
2 \\
1 \\
1 \\
1\end{array}$ & $\begin{array}{l}\text { A1 } \\
\text { A3 } \\
\text { A4 } \\
\text { A5 } \\
\text { A6 } \\
\text { E }\end{array}$ \\
\hline Bangalore, India (1976-1984) & $\begin{array}{l}1 \\
1 \\
1 \\
1 \\
4 \\
1 \\
1 \\
1 \\
1 \\
1 \\
1\end{array}$ & $\begin{array}{l}\text { A1 } \\
\text { A2 } \\
\text { A7 } \\
\text { A8 } \\
\text { B1 } \\
\text { B3 } \\
\text { B4 } \\
\text { B5 } \\
\text { B6 } \\
\text { B7 } \\
\text { F }\end{array}$ \\
\hline CDC Collection, USA 1974-1985) & $\begin{array}{l}2 \\
2 \\
1 \\
1\end{array}$ & $\begin{array}{l}\text { A2 } \\
\text { B3 } \\
\text { G } \\
\text { H }\end{array}$ \\
\hline
\end{tabular}

${ }^{*}$ Determined after digestion with Not $\mathbf{I}$ enzyme. 
a
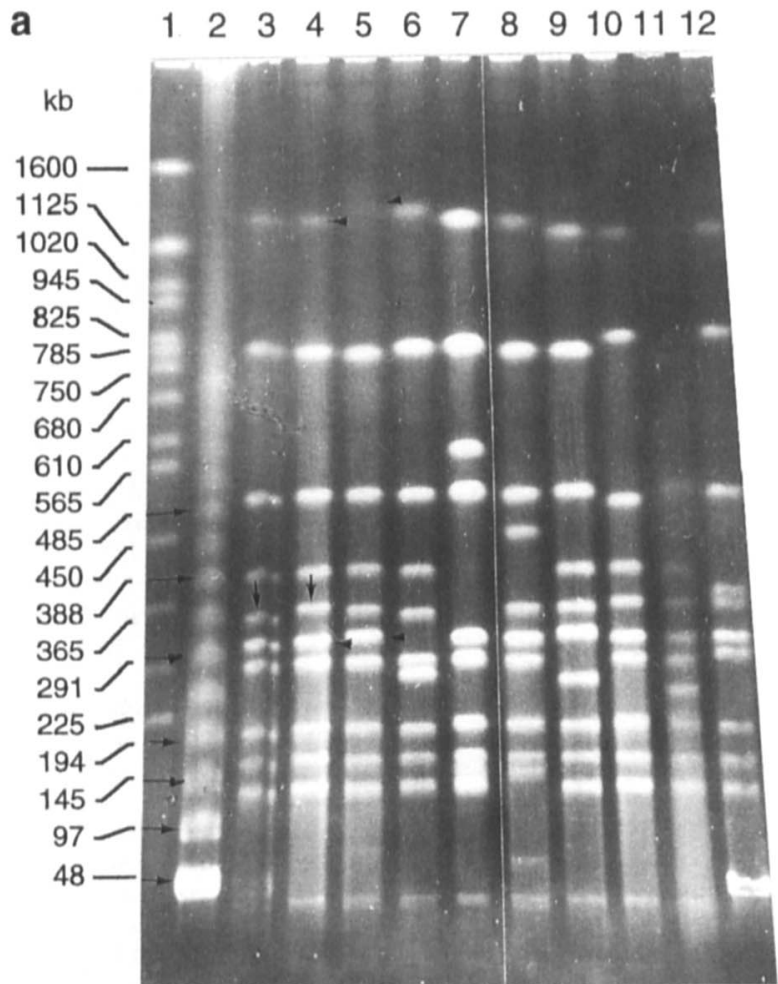

C

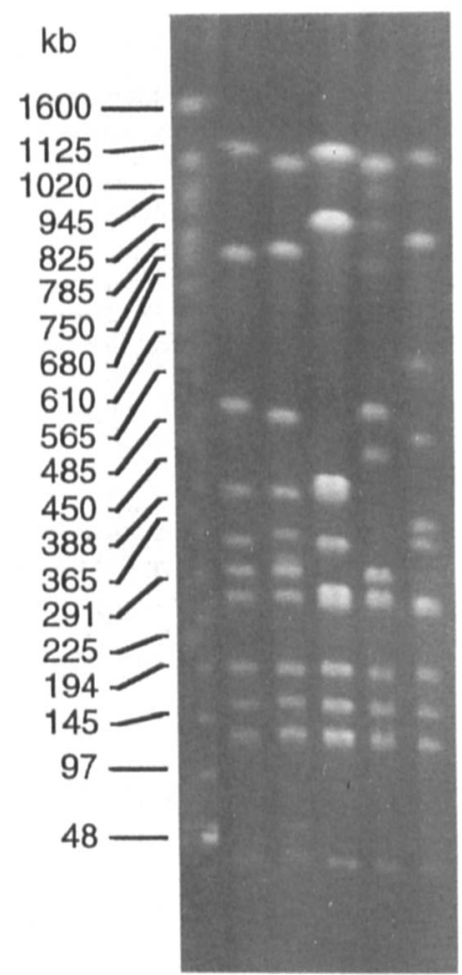

were isolates that were indistinguishable from the isolates that caused the epidemics (e.g., PFGE type A1, A2, B1). PFGE types A1 and A2, detected among the epidemic strains in the mid-1980s in Bangladesh and India, were present among the endemic strains in Bangalore in 1977-1978. PFGE type A2 was present among the CDC collection dated 1979. b
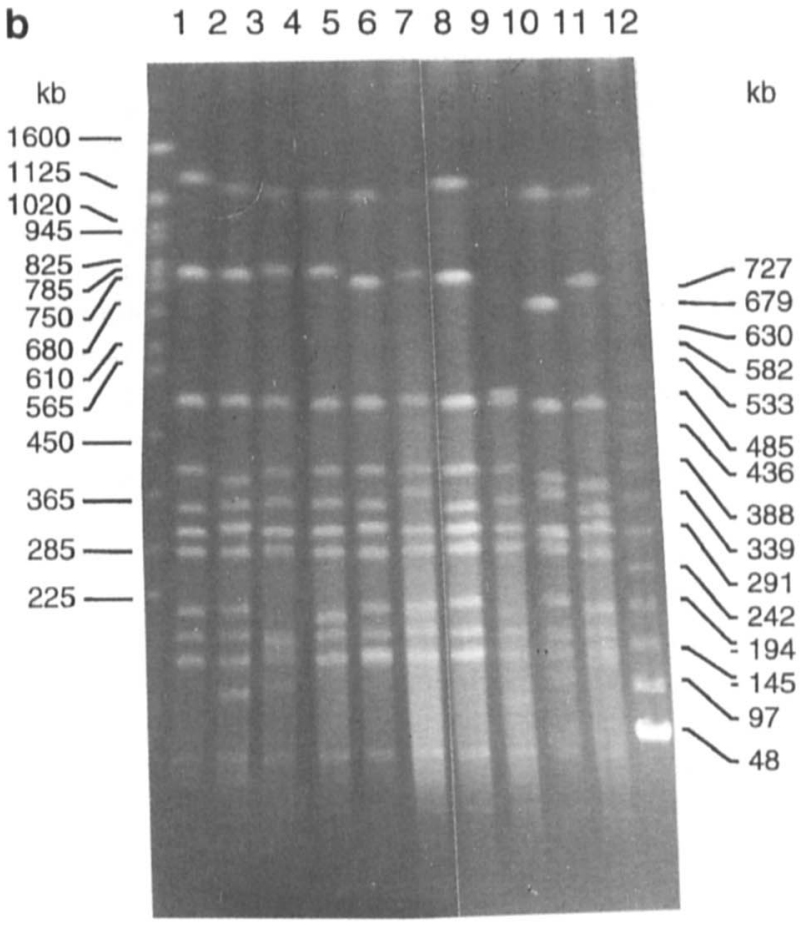

Fig. 1. Representative PFGE patterns of $S$. dysenteriae 1 isolates allowing discrimination of types and subtypes. (a) Lane 1, mol. wt marker: DNA from Sacch. cerevisiae $(225-2200 \mathrm{kbp}) ; 2$, mol.wt marker: $\lambda$ ladder (48$1000 \mathrm{kbp}) ; 3, \mathrm{~A} 1 ; 4, \mathrm{~A} 2 ; 5, \mathrm{~A} 3 ; \mathbf{6}, \mathrm{A} 4 ; 7, \mathrm{~A} 5 ; 8, \mathrm{~A} 6$; 9, A7; 10, B1; 11, B3; 12, B2. The differences in the mobilities of corresponding bands between subtypes A1 and $\mathrm{A} 2$ are indicated by vertical arrows, and those between the mobilities of corresponding bands between subtypes A2 and A3 are indicated by horizontal arrow heads. (b) Lane 1, Sacch. cerevisiae DNA; 2, A1; 3, A8; 4, B4; 5, B5; 6, B6; 7, B7; 8, A1; 9, C; 10, D; 11, E; 12, $\lambda$ ladder DNA. (c) Lane 1, Sacch. cerevisiae DNA $+\lambda$ DNA, 2, A1; 3, B1; 4, F; 5, G; 6, H.

\section{Discussion}

Preliminary studies showed that Not I gave the best discrimination of the strains. Hence, this endonuclease was used for typing of all isolates. The studies also showed that the patterns obtained were remarkably stable, as shown after repeated subcultures. 
Isolates obtained from Teknaf and Rangpur in Bangladesh were identical to the isolates obtained from Calcutta, India. This is not surprising, because these areas are geographically close, and a large epidemic encompassing these areas occurred during 1984-1986 $[6,11,12]$. Some epidemic and endemic isolates had common PFGE types, e.g., types A1, A2 and B1. This observation is similar to results obtained in studies in the USA and Japan, where some or all of the outbreak strains of $S$. sonnei were indistinguishable from endemic strains $[9,16]$. How an endemic strain becomes an epidemic strain is a matter of speculation. It could be due to the build-up of a susceptible population or to the acquisition of unknown virulence properties by the endemic strains that are not evident in PFGE analysis. The PFGE types A1 and A2 were first detected among the epidemic isolates in Bangladesh in the mid-1980s. They were also detected subsequently among the endemic isolates in Matlab in 1987 and in Dhaka in 1997. This suggests that the epidemic strains became endemic in these areas.

The present study has shown that the epidemic strains of $S$. dysenteriae type 1 were homogeneous and endemic strains were heterogeneous by PFGE. This suggests that, as with other bacteria, it is possible to apply the PFGE technique for typing of $S$. dysenteriae type 1 isolates.

This research was funded by the ICDDR,B: Centre for Health and Population Research, which is supported by countries and agencies which share its concern for the health problems of developing countries. Current donors providing unrestricted support include: the aid agencies of the Governments of Australia, Bangladesh, Belgium, Canada, Saudi Arabia, Sweden, Switzerland, the UK and the USA; international organisations including the United Nations Children's Fund (UNICEF). We thank Mr Manzurul Haque for secretarial assistance.

\section{References}

1. Ansaruzzaman M, Kibriya AKMG, Mitra AK, Sack RB, Albert MJ. Isolation of Shigella dysenteriae serotypes 11,12 , and 13 from patients with diarrhea in Bangladesh. J Clin Microbiol
1993; 31: $1392-1393$.

2. Bennish ML, Harris JR, Wojtyniak BJ, Struelens M. Death in shigellosis: incidence and risk factors in hospitalized patients. $J$ Infect Dis 1990; 161: 500-506.

3. Stoll BJ, Glass RI, Huq MI, Khan MU Banu H, Holt J. Epidemiologic and clinical features of patients infected with Shigella who attended a diarrheal disease hospital in Bangladesh. J Infect Dis 1982; 146: 177-183.

4. Tacket CO, Cohen ML. Shigellosis in day care centers: use of plasmid analysis to assess control measures. Pediatr Infect Dis $J$ 1983; 2: 127-130.

5. Yagupsky P, Loeffleholz M, Bell K, Menegus MA. Use of multiple markers for investigation of an epidemic of Shigella sonnei infections in Monroe County, New York. $J$ Clin Microbiol 1991; 29: 2850-2855.

6. Munshi MH, Haider K, Rahaman MM, Sack DA, Ahmed ZU, Morshed MG. Plasmid-mediated resistance to nalidixic acid in Shigella dysenteriae type 1. Lancet 1987; 2: 419-421.

7. Hinojosa-Ahumada M, Swaminathan BS, Hunter SB et al. Restriction fragment length polymorphisms in rRNA operons for subtyping Shigella sonnei. J Clin Microbiol 1991; 29: 2380-2384.

8. Tenover FC, Arbeit RD, Goering RV et al. Interpreting chromosomal DNA restriction patterns produced by pulsedfield gel electrophoresis: criteria for bacterial strain typing. $J$ Clin Microbiol 1995; 33: 2233-2239.

9. Brian MJ, Van R, Townsend I, Murray BE, Cleary TG, Pickering LK. Evaluation of the molecular epidemiology of an outbreak of multiply resistant Shigella sonnei in a day-care center by using pulsed-field gel electrophoresis and plasmid DNA analysis. J Clin Microbiol 1993; 31: 2152-2156.

10. Litwin CM, Leonard RB, Carroll KC, Drummond WK, Pavia AT. Characterization of endemic strains of Shigella sonnei by use of plasmid DNA analysis and pulsed-field gel electrophoresis to detect patterns of transmission. $J$ Infect Dis 1996; 175: 864-870.

11. Pal SC. Epidemic bacillary dysentery in West Bengal, India, 1984. Lancet 1984; 1: 1462.

12. Bennish M, Eusof A, Kay B, Weirzba T. Multiresistant Shigella infections in Bangladesh. Lancet 1985; 2: 441.

13. World Health Organization. Programme for control of diarrhoeal disease (CDD/93.3, Rev. 1). In: Manual for laboratory investigation of acute enteric infections. Geneva, World Health Organization. 1987: 9-20.

14. Smith CL, Klco SR, Cantor CR. Pulsed-field gel electrophoresis and the technology of large DNA molecules. In: Davies K (ed) Genome analysis: a practical approach. Oxford, IRL Press. 1988: 41-72.

15. Albert MJ, Bhuiyan NA, Talukder KA et al. Phenotypic and genotypic changes in Vibrio cholerae O139 Bengal. J Clin Microbiol 1997; 35: 2588-2592.

16. Matsumoto $M$, Susuki $Y$, Saito $M$, Ishikawa N, Ohta $M$. Epidemiologic study of Shigella sonnei from sequential outbreaks and sporadic cases using different typing techniques. Microbiol Immunol 1998; 42: 259-264. 